\title{
Early grinding systems in North-Western Europe: $A$ critical review of 15 years of techno-functional research
}

\author{
Caroline Hamon
}

\begin{abstract}
The alluvial valleys and loess plateaux of North-Western Europe were first colonised at the end of the 6th millennium BC by agricultural populations from Central Europe. They introduced a number of farming, architectural, craft and food processing techniques. Among their material culture, macrolithic tools played a major role as seen by polishers, symbols of the new technique of polished stone. They also introduced querns, tools essential to process cereals. This study of the Early Neolithic querns in this part of Europe aims to advance the understanding of technical systems and the economy of early Neolithic societies.
\end{abstract}

Keywords: Early Neolithic, north-western Europe, querns, grinding materials, operational sequence of manufacture, techno-functional analyses

Caroline Hamon, CNRS, Permanent researcher, UMR 8215 Trajectoires, Maison de l'archéologie, 21 allée de l'Université, 92023 Nanterre cedex, France, caroline.hamon@cnrs.fr

\section{Introduction}

The alluvial valleys and loess plateaux of northwestern Europe were colonised toward the end of the 6th millennium by the first agricultural populations originating in Central Europe. They introduced farming and architectural techniques, as well as specific crafts and foodstuffs. Macrolithic implements played a major role in their material culture. Stone polishers are representative of the newly discovered manufacture of bone and stone tools while saddle querns are essential to processing cereals. This current study of Early Neolithic querns in north-western Europe therefore forms part of the general study of early technical systems in the general framework of research on the economy of these early agricultural societies.

Querns in settlements were generally found either in refuse pits bordering houses or in "hoards". In addition to yielding notions as to processing foodstuffs, they also provide relevant data linked to other types of domestic crafts (pottery production, dye processing, etc). Furthermore, the study of their functional aspects yields data that is complementary to other types of analyses such as of flint, animal bone and antler implements. Moreover, recent research on grinding tools obliges us to renew and refine the vision of early querns that we advanced in a general survey ten years ago (Hamon 2006).

This current study is based on a corpus of about 1.400 grinding tools unearthed in domestic contexts at 20 Linear Pottery Culture (5100-4900 BC) settlements and 23 Villeneuve-Saint-Germain Culture (4900-4700 BC) settlements. The assemblage comprises 268 lower stones and 506 upper stones, as well as a variety of other stone tools, including 29 grinding slabs, 56 other grinders and 299 handstones. The tools come from a wide chrono-cultural area stretching from the Armorican Massif in Brittany (France) to the Hesbaye 
in southern Belgium. Detailed descriptions of these tools are based on petrographic, typo-morphologic and techno-functional analyses (Nierlé 1982; Hamon et al. 2011). This systemic approach renders it possible to grasp both their function and their role in the economy of Early Neolithic populations.

\section{Choosing the right rock}

The Paris Basin is a Tertiary sedimentary basin comprising a wide variety of sandstone outcrops. Early Neolithic querns were fashioned from sandstones originating from different geological layers (Sparnacien, Cuisien, Thanetian, etc.) in the valleys that cut through the basin. The proximity of the settlements to the outcrops explains, for the most part, the local or micro-regional origin of the materials.

The choice of the different materials depended the stone's properties (grain size, compactness and porosity) and the desired function of the tool (Schoumacker 1993; Delgado et al. 2009; Boyer and Fronteau 2011). In these contexts, quartzitic sandstones with a siliceous matrix were most often preferred for their hardness. These required, nonetheless, a great quantity of pecking to sharpen their grinding surface. By contrast, calcareous sandstones containing at times shell fragment inclusions presented naturally abrasive grinding surfaces. The drawback of the stones with shell inclusions was the rapid wear of their working surface.

Two systems of rock procurement seem to have coexisted. The first was that of prying out of surface blocks or slabs from specific outcrops. The second was collection of rolled surface blocks from alluvial deposits (Hamon 2006). These two types of systems of procurement distinguish themselves from the more simple, opportunistic collection of surface material (Hamon and Milleville 2006).

The first procurement system corresponds to that of the prying out of angular blocks or slabs of high quality from specific bedrock outcrops. Fashioning, after extraction, required a significant amount of roughing out by means of chipping and flaking of the slab's edges and dorsal side (Hamon and Samzun 2004; Praud et al. 2010). It must be noted, nonetheless, that to date, no extraction site of this type has been identified in the field for the Early Neolithic in north-western Europe. It is also noteworthy that subsequently, in the Late Neolithic, rough blocks were extracted or mined in pits in other regions of France (Jaccottey and Milleville 2007; Jaccottey and Milleville 2010).

The second system of block procurement is that of collecting rolled surface blocks from alluvial deposits. These were chosen for their size and shape, close to that of the final product. This reduced the time invested in fashioning the grinder's ends and edges. Querns manufactured from transported stones present rolled surfaces that are easily identified by their patina. This mode of procurement concerns, for the most part the upper stones, as small rolled stones in alluvial deposits of the Seine River Basin are more frequent than larger blocks better suited for lower stones.

Sandstone was the preferred rock for saddle quern manufacture in most Linear Pottery Culture sites in Europe. This rock therefore can be considered a cultural trait in its own right that is characteristic of the first agricultural populations of continental Europe as these populations were willing to trek up to 60 kilometres to obtain it (Gehlen and Zimmermann 2012). It must be noted, however, that sandstone was not the only available or appropriate type of rock. There are along the fringes of the Paris Basin, among the crystalline outcrops of the Morvan or Armorican Massifs, several other abrasive rocks such as conglomerates, granites and granodiorites (Fig. 1) that were sought out for use as both lower and upper stones (Hamon 2014; Blanchet et al. 2010; Giraud et al. 2012; Hamon 2011).

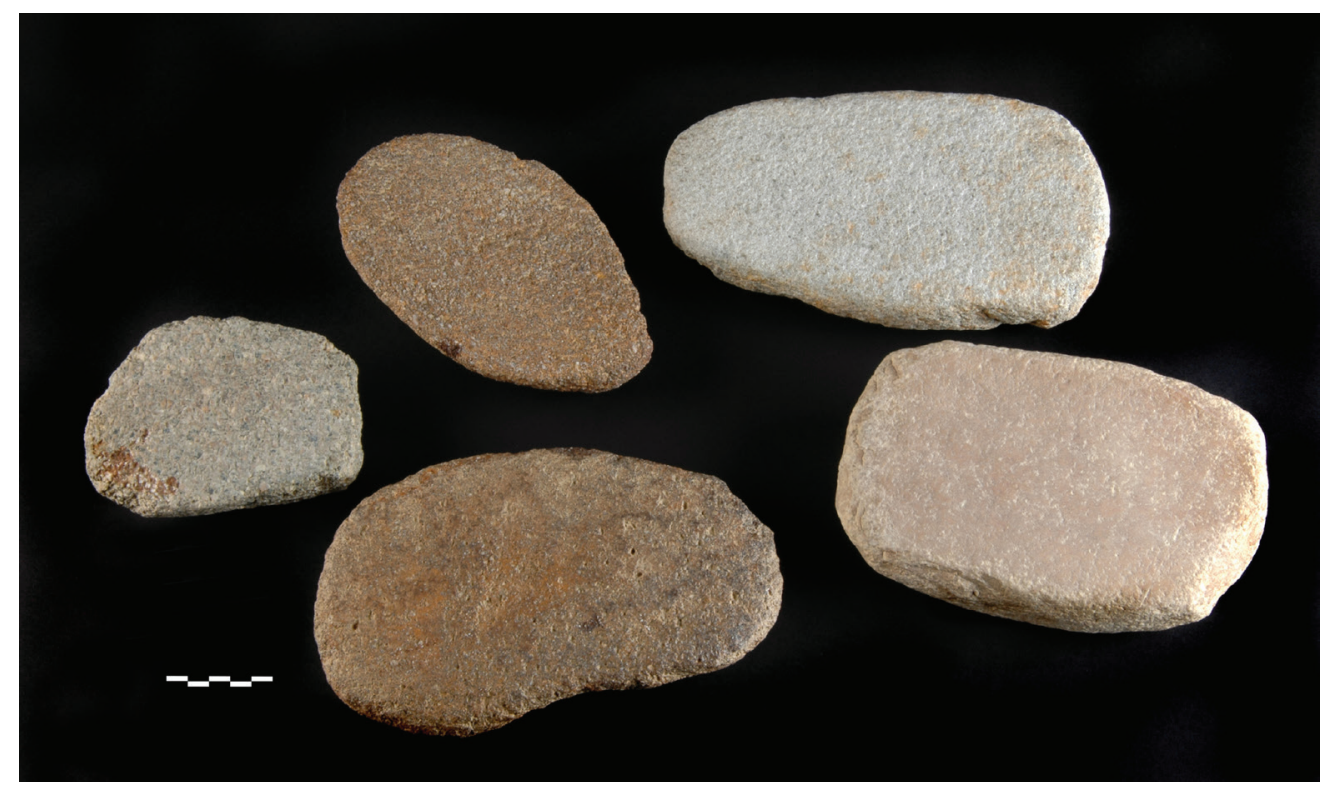

Fig. 1: Examples of the diversity of raw materials for the grinding stones at the site of Pluvignon à Betton, Brittany (France) (Photograph by H. Paitier, Inrap). 


\section{Fashioning the grinding tools}

Recent research on technological aspects of Early Neolithic querns of north-western Europe renders it possible to specify the operational sequence and organisation of the different phases of quern production with a higher degree of precision.

The most complete production operational sequence observed to date involves the flaking of a block's edges downward from the striking platform (its future grinding surface) followed by fashioning its dorsal side and its ends. This was followed by a pecking phase to regularise the entire outer surface and delimit the grinding surface's contour by means of "retouches" (Hamon 2006). It appears that this operational sequence was directly applied to fashion tools from rocks other than sandstones, as is the case at Betton in Brittany (Blanchet et al. 2010) or Colombelles in Normandy (Billard et al. 2014). This would suggest that this operational sequence was not simply a quern maker's adjustment to the mechanical properties of the rock, but responded to a technical standard shared by Early Neolithic communities in north-western Europe.

The initial model of quern production suggested that the first stages of fashioning took place at the source, where the block was collected (alluvial deposit). These areas were separated from those of consumption where the grinding surfaces of the tools were sharpened before use (Hamon 2009; Fig. 2a). Although this model is still generally valid, new observations have led us to amend the view of a separation of work between places of production and consumption. In fact, certain phases of the quern production operational sequence, usually undertaken at the place of extraction, take place at the settlement (Fig. 2b).

This is evidenced by rough, unworked blocks collected from alluvial deposits were found in pits outside the houses at the settlement of Colombelles, Normandy (Billard et al. 2014). Since their size and morphology, on the whole, correspond to that of grinding tools, it is likely that they were transported to the settlement to be fashioned. Several roughouts in different phases of production (Billard et al. 2014), as well as flakes interpreted as debitage debris, were also found in some of the pits. At Loison-sous-Lens (Pas-de-Calais) these types of roughouts seem to have been abandoned either after a rough flaking or after a first phase of testing of the grinding surfaces (Praud et al. 2010). Characteristic of this preliminary work phase are also finds bearing traces of coarse pecking to even the surface and a rough removal of irregularities of the grinding surface.

Recent research also offers new data regarding quern fashioning and the grinding surface dressing sequence. The refitting of chipping flakes with a block (like pieces of a puzzle) at the site of Luzancy (Hamon 2013) suggests at least two modes of primary block reduction.
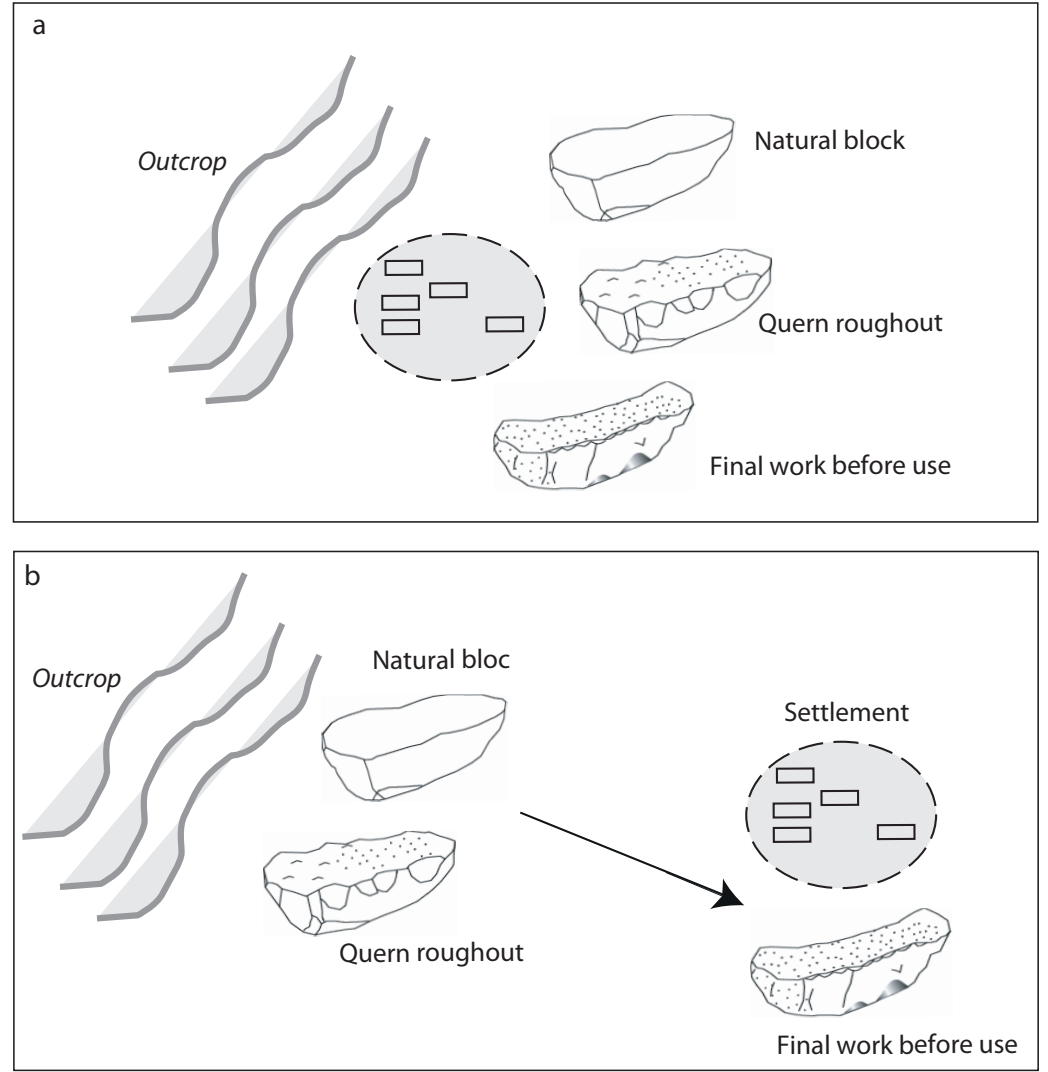

Fig. 2: Schemas of the two operational sequences for the manufacture of sandstone querns (upper and lower stones) a. different steps take place at the source (alluvial deposit outcrop); b. final grinding stone surface work undertaken at the settlement (after Hamon 2013, fig. 76). 
In one case flaking took place from the extremity while the other indicates flaking took place from the edge. The analysis of a concentration of debitage debris at Ocquerre (Hamon 2009) has also revealed that working the dorsal side and the edges of the querns along the so-called "central core" yielded few flakes that can be mounted when the quern itself is missing (Fig. 3). Finally, a sequence of at least three successive levels of debitage intended to reshape a quern's edge using the grinding surface as a striking platform was identified at Luzancy (Hamon 2013).

The spread of fashioning flakes inside specific houses of settlements, such as at Cuiry-lès-Chaudardes, Aisne (Hamon 2006), as well as the existence of quern hoards, at times in very large numbers in specific households, notably at Hainaut (Constantin et al. 1975; Hamon 2008b), suggest that specialised craftsmen, linked to one of the households of the village, were entrusted with grinding tool manufacture and maintenance (Hamon 2008c).

\section{Adapting grinding systems}

Early Neolithic settlement excavations reveal a number of grinding systems with a significant typological variety of saddle querns. The majority of the whole (unbroken) examples come from hoards, archaeological features that provide a precise portrait of the different types of mills that served simultaneously.

A certain number had flat grinding surfaces. These were most often either hardly fashioned and thin (4 and $5 \mathrm{~cm}$ ) slabs (e.g. Loison-sous-Lens, Pasde-Calais) (Praud et al. 2010) or fashioned from roughly worked thick blocks (e.g. Berry-au-Bac, Picardy) (Hamon 2006). Thick querns, in turn, bear proximal edges associated with highly concave grinding surfaces. According to recent studies in Western Europe (Monchablon 2014; Donnart 2011), these are characteristic of the Late Neolithic. It must be noted that these highly concave and flat grinding surfaces cannot be viewed simply as the product of different degrees of wear. They, in fact, point to different types of querns. These differences also relate both to the way the stones were anchored during their use and the type and range of the actions to which they were subject. Furthermore, as seen in certain hoards such as that of SaintDenis (Ile-de-France), these different quern types appear to have functioned simultaneously (Hamon and Samzun 2004).

Despite their different morphological and typological attributes, both quern types were operated with short upper stones of a length equal or less that of the width of the lower stone. With the advent of the Linear Pottery Culture in the Paris Basin, we observe, in fact, that the abandonment of the common long overlapping upper stones coincides with the advent of shorter upper stones, a type that is prevalent throughout all of Europe (Zimmermann 1988; Constantin 1985; Pavlu 2000; Jadin 2003; Hamon and Goemaere 2007). The other grinding system used plano-convex upper stones whose length exceeded their narrow lower stones. After a certain amount of use, these upper stones developed very pronounced distal ends and a strongly marked concavity in their centre (Fig. 4). These features point to a transmission of the miller's driving force through the ends of the upper stones, contrary to that of the short upper stones where the transmission was centred on the stone's back (Hamon 2008b).

Upper stones or rubbers, furthermore, present a wide variety of sizes and shapes, always responding to identical criteria as to their use. The first criterion

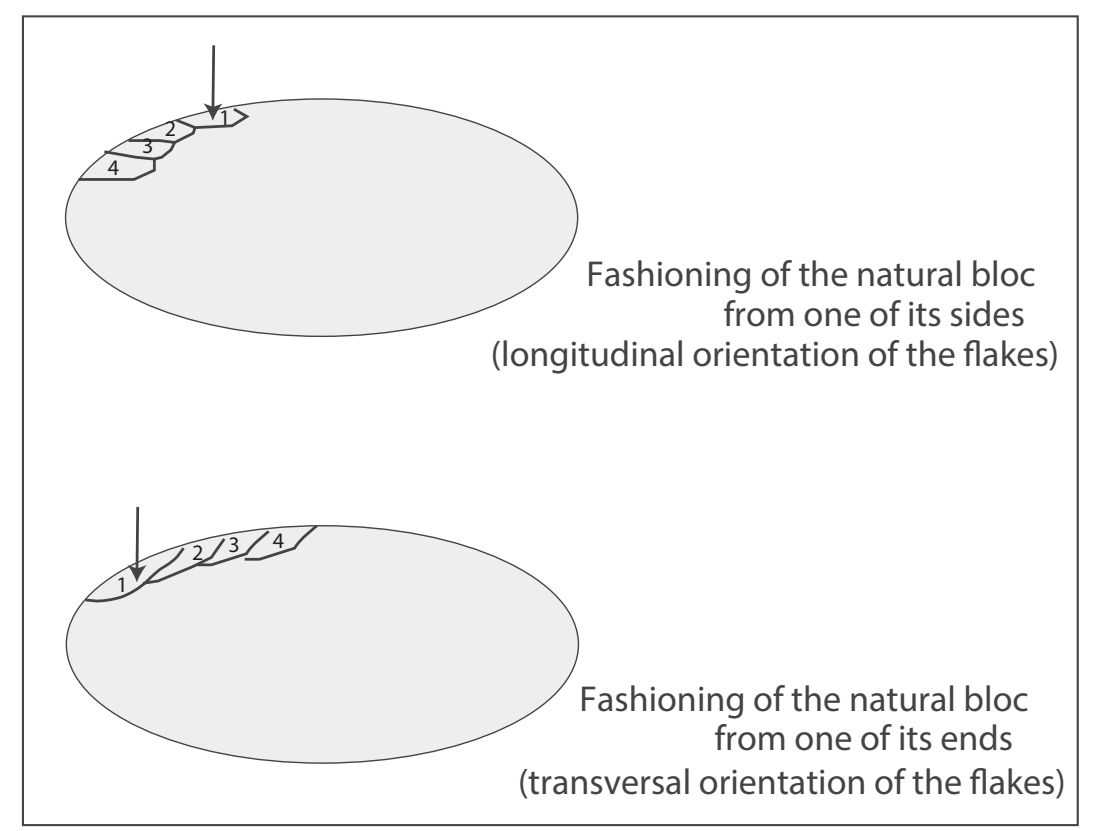

Fig. 3: Schematic representation of the two initial sequences of quern reduction based on refitted debitage flakes (modified after Hamon 2013, fig. 70). 


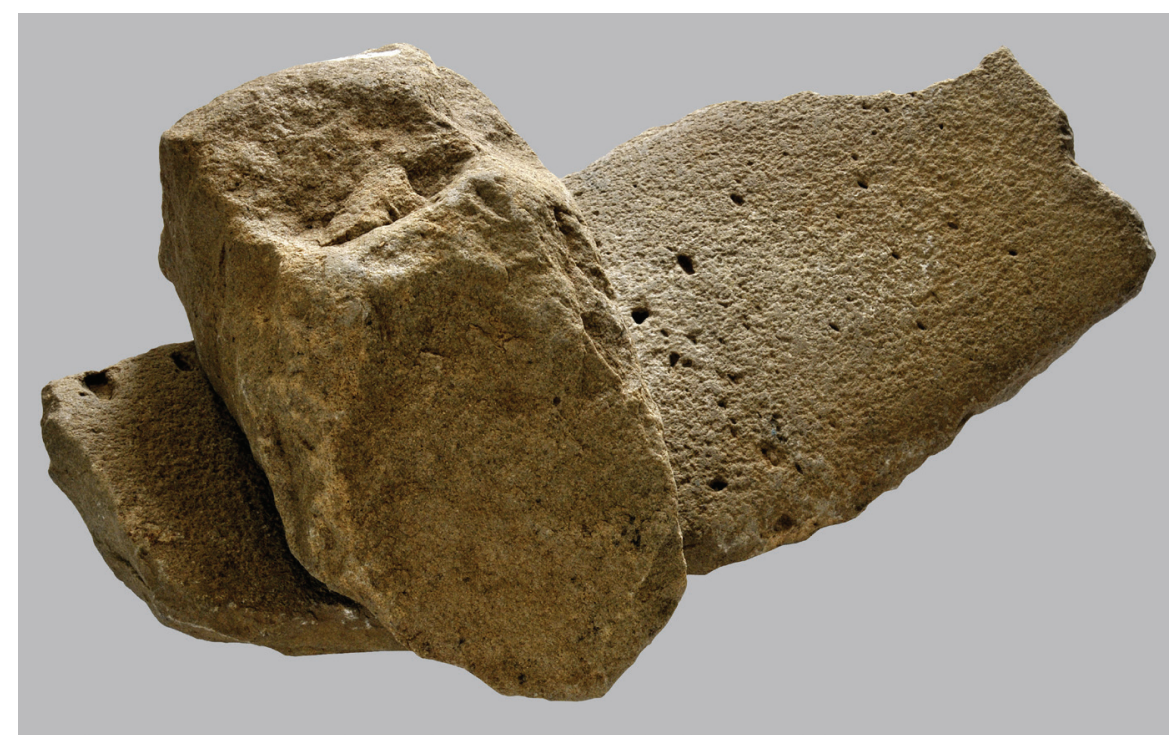

Fig. 4: Lower stone and its overlapping upper stone (molette débordante) of sandstone from Darion - "Colia" (Hesbaye, Belgium) (Photograph by P. Cattelain, IRSNB Collection).

was the need to prepare a zone of the surface adapted for the palm of the hand. The second was to fashion a range for the distal phalanges of the fingers to assure a firm grip so as to complete the backward motion. Noteworthy is an assemblage of very small upper stones (e.g. Berry-au-Bac, Picardy) (Hamon 2006) that either suggest a different type of use or possibly a special type intended for children. Otherwise, in spite of their high degree of fragmentation, two quern models stand out (Hamon 2006; Monchablon 1999).

Moreover, a few quern assemblages include grinding slabs bear traces of wear indicative of circular (reused querns at St. Denis (Ile-de-France) (Hamon and Samzun 2004), oval or multidirectional use (Luzancy, Ile-de-France) (Hamon 2013). It is noteworthy that these types of wear are indicative of grinding differing from that of cereals.

The assemblages of the Early Neolithic of northwestern Europe thus reveal a wide variety of quern types that were in use more or less simultaneously in the settlements of the Linear Pottery Culture. This suggests that quern types correspond not only to evolutionary or cultural criteria, but are the result of a number of other factors related to their function and the availability of raw material.

\section{Why pound and grind?}

Recent research resorting to a stereoscopic microscope to examine use-wear (traceology) analysed an assemblage of approximately 500 tools (221 querns and grinders, 20 grinding slabs, 44 handstones) (Hamon 2014). The study compared the traces visible on the different types of sandstones, as well as on other types of rocks used to process foodstuffs or for crafts. The study was designed to identify the tool's duration and the differences of quality of sandstones for each of the following actions: milling, grinding, abrading/polishing (Hamon 2003; 2008). The more noteworthy results have led to identification of the nature (animal, mineral and vegetable), texture, intensity of use, as well as the state (dry, fresh, etc.) of a series of different materials (Hamon and Plisson 2008; Adams et al. 2009).

The overview of the results indicates that although querns mainly served to grind grains (74\%), they also saw service to process other materials such as minerals (including dyes 14\%) and bones (5\%), presumably for pottery temper. These results therefore also highlight the important role of querns and other grinding tools not only to process foodstuffs, but in the operational sequence of other crafts such as pottery and dye manufacture (Fig. 5).

Other tools potentially involved in grinding operations, notably handstones, also reveal a great diversity of use. Handstone served as much for grinding and dehusking plants (and at times cereals), as well as for grinding both hard and soft minerals such as dyes and animals parts. These tools therefore saw use both in the different stages of food processing, as well as in craft-works.

The results of this recent research has also led to delve into the question of the multi-functionality of Neolithic grinding tools. This question cannot, from our perspective, be addressed without placing the tools in their context (e.g. Hamon 2008a; 2009). Multi-functionality is related, in part, to the degree of specialisation of an action (seen through the morphology and change of shape of the grinding surface), as noted in many ethnographic studies (Katz 2003; Roux 1985). The complexity of the parameters in operations involving pounding (direct percussion - "percussion lancée") also partly explains the difficulties in interpreting the precise function of pounding tools.

The difficulties of interpretation also stem from the degree of precision of the methods put to use 

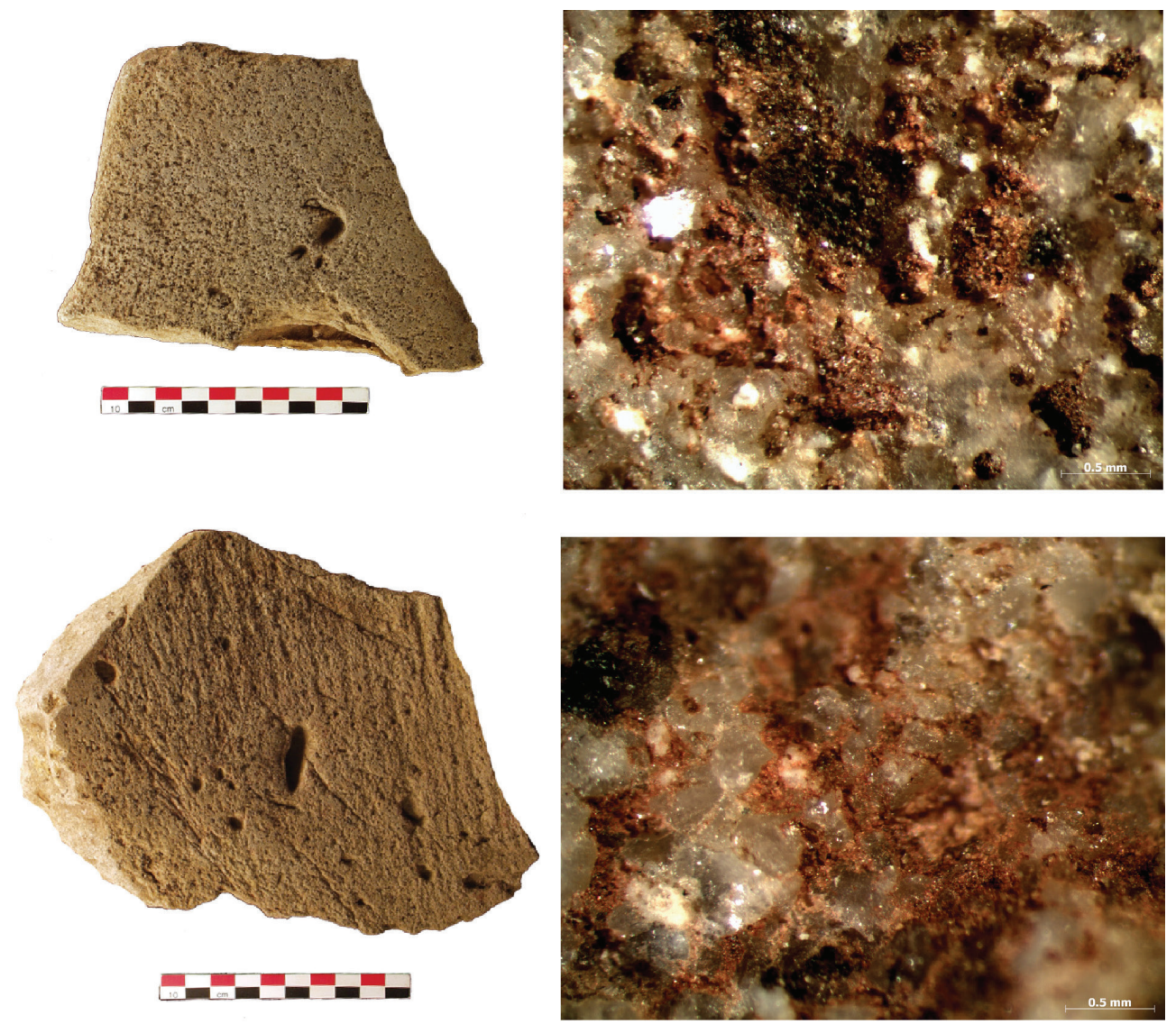

Fig. 5: Fragments of cereal querns and grinders from Remicourt En bia Flo (Hesbaye, Belgium), used for cereal grinding and then reused for the processing of red colouring material (after Hamon 2007).

to characterise the processing of materials. The ease of identification of wear traces on tools used to grind grains can be explained, in part, by their extended period of use (up to several years). The properties of the materials themselves, however, provide a sufficient degree of accuracy to distinguish between grinding and dehusking. They probably also conceal other traces related to processing either plant materials or soft animal substances (notably meat), a type of wear that is usually not identified in functional analyses (Hamon 2014).

It must also be noted that use-wear analyses generally only identify either the tool's last or primary use. In some cases a combination of methods of functional analysis, such as the combination of optical and residue analyses, offers a more complete view of a tool's function. When conditions of preservation are favourable, residue (phytoliths and starches in particular) analyses identify the families or parts of the original plants or even, at times, their nature (Procopiou et al. 2002; Hamon et al. 2011).

\section{Quern find context, use and disposal}

The understanding of the context of the find, coupled with a fine reading of its technology, is essential to fully grasp the stage of a tool's use. Ethnography has demonstrated that querns and other grinding tools have long, complex life cycles subject to multiple phases of dressing, repair and reuse. The rate of development of wear, the frequency of dressing and the gradual reduction of size, are factors directly related to the intensity and nature of use.

A pitfall regarding Early Neolithic querns is that their archaeological find spot is almost exclusively in a context of primary or secondary disposal (Allard et al. 2013) and not in situ, that is, in the position they saw use. Furthermore, they are at times recovered in structures of combustion or reused in architecture. Furthermore, querns cannot be considered to be in situ even when they are discovered in preserved floor levels of houses or concentrated in what are presumed to be areas of storage behind houses (Bostyn et al. 1991; Hamon 2006).

Querns recovered in hoards are particularly interesting for techno-functional research as these features contain whole (unbroken) querns that were deliberately "extracted" from their life cycle and can reflect different stages of use. The techno-functional study of the Saint-Denis hoard indicates that two of the five querns were fashioned from a single large grain quern that broke into two parts. Traces evidencing circular motions point to a different type of secondary use (Hamon and Samzun 2004). A third quern evidences a succession of distinct uses. Originally it served as a grain mill driven with a to-and-fro motion. Then, after it broke, it 
served to grind hard animal parts by means of a circular motion. This analytical approach therefore allows speculation as to the primary and secondary functions, as well as the cycles of reuse, of ancient tools.

In a few exceptional cases it is possible, by observing the use-wear, to identify the reuse of cereal querns for grinding dyes. Certain studies indicate that reused fragments of broken querns served, in fact, to grind dyes into powder. This is quite common at sites in Hesbaye in Belgium (Hamon and Goemaere 2007), in the Netherlands (Van Gijn and Verbaas 2009) and in the Paris Basin (Bostyn et al. 2012).

Finally, certain archaeological contexts suggest that querns had a specific, possibly symbolic, character (Hamon 2009). This is the case, for example, of rejected and burned querns recovered in silos (Augereau et al. 2006; Delor 1994) or placed as grave goods at the feet or near the head of the dead (Farrugia 1992; Spatz 1999).

\section{Conclusion}

Although grinding tools, contrary to pottery or other lithic materials, do not serve as fine chronological markers, they do offer insight not only on activities linked to cereal processing, but on other domestic crafts of the Early Neolithic of north-western Europe. The systemic analysis of these types of tools takes into consideration the operational sequence (from the procurement of the raw material to final discarding) that sheds light on aspects as to their production, their degree of functional specialisation, as well as their symbolic value. Querns studies are therefore central to advancing the understanding of Neolithic economies (Hamon and Hachem 2014).

\section{Bibliography}

Adams, J., Delgado, S., Dubreuil, L., Hamon, C., Plisson, H., AND Risch, R. (2009). Functional analysis of macro-lithic artefacts. In: F. STERnKe, L. Eigeland and L. Costa (eds). Non-flint Raw Material Use in Prehistory Old Prejudices and New Direction, 15TH UISPP congress, Lisbon-September 2006, BAR International Series, 1939.

Allard, P., Hamon, C., Bonnardin, S., Cayol, N., Chartier, M., Coudart, A., Dubouloz, J., Gomart, L., Hachem, L., Ilett, M., Meunier, K., Monchablon, C. and Thevenet, C. (2013). Linear Pottery domestic space: taphonomy, distribution of finds and economy in the Aisne valley settlements. In: C. Hamon, P. Allard and M. Ilett (eds). The Domestic Space in LBK Settlements. Verlag Marie Leidorf GmbH Rahden/Westf: 9-28.

Augereau, A., Hamon, C. And Meunier, K. (2006). L'habitat rubané et Villeneuve-Saint-Germain à Gurgy " les Grands Champs » (Yonne). In: P. DuhameL (dir.). Impacts interculturels au Néolithique moyen. Du terroir au territoire: sociétés et espaces, Actes du XXVe colloque sur le Néolithique, 20-21 octobre 2001- Dijon, Supplément de la Revue archéologique de l'Est, 25.

Billard, C., Bostyn, F., Hamon, C. and Meunier, K. (2014). L'habitat du Néolithique ancien de Colombelles "Le Lazzaro » (Calvados). Mémoire 58. Société Préhistorique Française. Paris.

Blanchet, S., Forre, P., Fromont, N., Hamon, C. and Hamon, G. (2010). Un habitat du Néolithique ancien à Betton " Pluvignon » (Ille-et-Villaine) : présentation synthétique des différents ensembles mobiliers. In: C. Marcigny, G. SAN JuAN and C. Riche (eds). Quoi de neuf à l'ouest: cultures, réseaux et échanges des premières sociétés néolithiques à leur expansion. Actes du 28 e colloque interrégional sur le Néolithique. Presses Universitaires de Rennes.

Bostyn, F., Hachem, L. and Lanchon, Y. (1991). Le site néolithique de Jablines "la Pente de Croupeton" (Seine-et-Marne): premiers résultats. In: Actes du colloque néolithique de Châlons-sur-Marne. ARPEPP, 45-81.

Bostyn, F., Arbogast, R.-M., Cayol, N., Hamon, C., Lorin, Y. AND Prodeo, F. (2012). Le site d'habitat Villeneuve-Saint-Germain de Pontpoint « le fond de Rambourg »(Oise). Gallia Préhistoire 54: 47-112.

Boyer, F. and Fronteau, G. (2011). Les géomatériaux meuliers: de l'identification des sources géologiques à la définition de catégories de gisements. In: O. Buchsenschutz, L. Jaccottey, F. Jodry, And J. L. Blanchard (dir.). Évolution typologique et technique des meules du Néolithique à l'an mille sur le territoire français. Table ronde de Saint-Julien-sur-Garonne (F), du 2 au 4 octobre 2009. 23ème supplément Aquitania: 121-35.

Constantin, C. (1985). Fin du Rubané, céramique du Limbourg et post-Rubané. Le néolithique le plus ancien en Bassin parisien et en Hainaut. B.A.R. International Report, 273. Oxford.

Constantin, C. Farruggia, J-P., Plateaux, M. And Demarez, L. (1978). Fouille d'un habitat néolithique à Irchonwelz (Hainaut occidental). Revue archéologique de l'Oise, 13: 3-20.

Delgado-Raack, S., Gómez-Gras, D. and Risch, R. (2009). The mechanical properties of macrolithic artifacts: a methodological background for functional analysis. Journal of Archaeological Science 36: 1823-31.

Delor, J.-P. (1994). Gurgy "les Plantes du Mont": conservation, préparation et cuisson des aliments au début du Néolithique moyen. In: M. Joly AND L. MARChAND (eds). Boire et manger en Bourgogne, actes des rencontres ARIA Bourgogne, Auxerre, mars 1992. Cahiers archéologiques de Bourgogne 5: 19-22. 
Donnart, K. (2011). Le matériel de mouture de l'habitat campaniforme / Bronze ancien de Beg ar Loued (Île Molène, Finistère): étude préliminaire. In: O. Buchsenschutz, L. Jaccottey, F. Jodry AND J.L. Blanchard (dir.). Évolution typologique et technique des meules du Néolithique à l'an mille sur le territoire français. Table ronde de Saint-Julien-sur-Garonne du 2 au 4 octobre 2009. 23ème supplément, Aquitania, 438.

FARruggia, J.-P. (1992). Les outils et les armes en pierre dans le rituel funéraire du Néolithique danubien. BAR International Report, 581. Oxford.

Gehlen, B. And Zimmermann, A. (2012) Rohmaterial und Grundformspektren als historische Quellen: Beispiele aus dem Frühneolithikum Mitteleuropas. In: H. Floss. Steinartefakte vom Altpaläolithikum bis in die Neuzeit Tübingen. Publications in Prehistory. Kerns: 659-78.

Giraud, P., Juhel, L., Hamon, C., Germain, C., Savary, X. AND JAN, D. (avec les contributions de C., RiQuier et de J.-P., Caspar [†]) (2012). L'habitat du Néolithique ancien de Fontenay-le-Marmion "Le Grand Champ/ Le chemin Haussé » (Calvados). Revue archéologique de l'Ouest, 29.

Hachem, L. and Hamon, C. (2014). Linear pottery household organization: an economic model. In: A. Whittle And P. Bickle (eds). Early Farmers: The View from Archaeology and Science, OUP/British Academy, Proceedings of the British Academy, Vol. 198.

Hamon, C. (2003). De l'utilisation des outils de mouture, broyage et polissage au Néolithique en Bassin parisien: apports de la tracéologie. Bulletin de la société préhistorique française, 100-1: 101-116.

Hamon, C. (2005). Quelle signification archéologique pour les dépôts de meules néolithiques dans la Vallée de l'Aisne? In: G. Auxiette and F. Malrain (eds). Hommages à Claudine Pommepuy, Revue archéologie de Picardie, $\mathrm{N}^{\circ}$ spécial 22 (Amiens 2005): 39-48.

Hamon, C. (2006). Broyage et abrasion au Néolithique ancien. Caractérisation technique et fonctionnelle des outillages en grès du Bassin parisien. BAR International Reports, S1551. Oxford.

Hamon, C. in collaboration with E., Goemaere (2007). Outils de broyage et outils d'abrasion en contexte rubané de Hesbaye: premiers résultats d'une analyse techno-fonctionnelle. Notae Praehistoricae 27: 109-19.

Hamon, C. (2008a). Functional analysis of stone grinding and polishing tools from the earliest Neolithic of north-western Europe. Journal of Archaeological Science 35: 1502-120.

Hamon, C. (2008b). Meules rubanées, meules blicquiennes: nouvelles réflexions sur les dépôts du Hainaut (Belgique). In: L. Burnez-Lanotte, M. Ilett and P. Allard (dirs.). Fin des traditions danubiennes dans le Néolithique du Bassin parisien et de la
Belgique (5100-4700 av. J.C.). Autour des recherches de Claude Constantin. Mémoire XLIV de la Société Préhistorique française: 197-208.

Hamon, C. (2008c). The symbolic value of grindingstone hoards: technical properties of Neolithic examples. In: C. Hamon AND B. Quilliec (eds). Hoards from the Neolithic to the Metal Ages. Technical and codified practices. Session of the $\mathrm{XI}^{\text {th }}$ Annual Meeting of the European Association of Archaeologists. BAR International Series, 1758. Oxford: $120 \mathrm{p}$.

Hamon, C. (2009a). L'outillage en grès. In: I. Praud, F. Bostyn, M.F. Dietsch-Sellami, C. Hamon, Y. Lanchon AND L. Michel, in collaboration with J.P. CASPAR $\dagger$, E. Martial and D. Vachard. Le Néolithique ancien dans la Basse vallée de la Marne et ses affluents: un site d'habitat producteur de lames en silex tertiaire de la fin du VSG à Ocquerre (Seine-et-Marne). Société préhistorique française, Travaux 9: 77-97.

Hamon, C. (2009b). The Functional and Symbolic Value of Grinding Stone Tools from the Late Bandkeramik of North-Western Europe. Current Research Internet Archaeology, 26.

http://intarch.ac.uk/journal/issue26/hamon_index. html.

Hamon, C. (2011). L'outillage macrolithique. In: A. Augereau and P. Chambon. Les occupations néolithiques de Macherin à Monéteau (Yonne). Société Préhistorique française, Mémoire LIII: 78-85.

Hamon, C. (2013). Le macro-outillage lithique. In: Y. Lanchon and F. Bostyn (dir.). Un hameau du Néolithique ancien. Le Pré aux Bateaux à Luzancy (Seine-etMarne). Collection Recherches archéologiques, CNRS éditions-Inrap: 115-33.

Hamon, C. (2014). Ten Years of Use-Wear Analysis of Early Neolithic Macrolithic Tools from North-Western Europe: Limits and Contribution. In: J. MARREIRos, N. Bicho and J. F. Gibaja. International Conference on Use-Wear Analysis. Use-Wear 2012. Cambridge Scholars Publishing: 103-13.

Hamon, C., Emery-Barbier, A. and Messager, E. (2011). Quelle fonction pour les meules du Néolithique ancien de la moitié nord de la France ? Apports et limites de l'analyse phytolithique. In: F. Bostyn, E. Martial and I. Praud (eds). Le Néolithique du Nord de la France dans son contexte européen: habitat et économie aux $4 \mathrm{e}$ et $3 \mathrm{e}$ millénaires avant notre ère, Actes du 29e colloque interrégional sur le Néolithique, Villeneuve-d'Ascq, 2-3 octobre 2009. Revue archéologique de Picardie, Numéro Spécial 28: 515-22.

Hamon, C., Farget, V., Jaccottey, L., Milleville, A., and Monchablon, C. (2011). Propositions de normes de dessin et d'une grille d'analyse pour l'étude du matériel de mouture à va-et-vient du Néolithique l'âge du Fer. In: O. Buchsenschutz, L. Jaccottey, F. Jodry and J.L. Blanchard (eds). Évolution typologique et 
technique des meules du Néolithique à l'an mille sur le territoire français. Table ronde de Saint-Julien-surGaronne du 2 au 4 octobre 2009, 23ème supplément. Aquitania: 39-50.

Hamon, C. And Milleville, A. (2006). La meule rhabillée, le plus simple appareil ? Fabriquer une meule au Néolithique. In: L. Astruc, F. Bon, V. LÉA, P-Y. Milcent and S. Philibert (eds). Normes techniques et pratiques sociales. De la simplicité des outillages pré et proto historiques, XXVIe rencontres internationales d'archéologie et d'histoire d'Antibes. Éditions APDCA (Antibes 2006): 173-83.

Hamon, C. and Plisson, H. (2008). Which analytical framework for the functional analysis of grinding stones? The blind test contribution. In: L. Longo and N. SkaKun (dir.). "Prehistoric Technology" 40 years late, Functional studies and the Russian legacy. BAR International Series, 1783: 29-38.

Hamon, C. And SAmzun, A. (2004). Une fosse Villeneuve-Saint-Germain final à Saint Denis "Rue du Landy ": un dépôt de meule inédit en Ile-deFrance. Internéo 4: 17-28.

Jaccottey, L. AND Milleville, A. (2007). Schéma d'occupation interrégional: l'exploitation du massif de la Serre (Jura, France) et la diffusion du matériel de mouture au Néolithique. Archaeologia Mosellana, 7: 185-207.

Jaccottey, L. And Milleville, A. (2010). Aux origines de la meule: premiers exemples de carrières de moulins type "va-et-vient ", Massif de la Serre, Jura. In: A. Beeching, É. Thirault and J. Vital. Économie et société à la fin de la Préhistoire. Actualité de la recherche. Actes des $7 e$ Rencontres méridionales de Préhistoire récente tenues à Bron (Rhône), 3 et 4 novembre 2006: 109-23.

JADIN, I. (2003). Trois petits tours et puis s'en vont...la fin de la présence danubienne en moyenne Belgique. ERAUL 109. Liège.

Katz, E. (2003). Le metate, meule dormante du Mexique. In: M. Barboff, F. Sigaut, C. Griffin-Kremer AND R. Kremer (eds). Meules à grains. Ibis Press. Maison des Sciences de l'Homme. Paris: 32-50.

Monchablon, C. (1999). Le matériel en grès et calcaire. In: Hachem L. (dir.). Bucy-le-long "La Fosselle", Rapport de fouille de sauvetage urgent. Service régional de Picardie. Amiens.

Monchablon, C. (2005). Le matériel de mouture, de broyage et de polissage. In: F. GiLigny (dir.). Louviers "La Villette" (Eure), Un site néolithique moyen en zone humide. Documents Archéologiques de l'Ouest. Rennes: 149-61.

Monchablon, C. (2014). Les meules de la fin du Néolithique dans le nord de la France: premiers résultats typo-chronologiques. In: C. Louboutin and C. VERJUX (eds). Zones de production et organisation des territoires au Néolithique. Espaces exploités, occupés, parcourus. Actes du 30e colloque interrégional sur le Néolithique (2011, Tours). Revue Archéologique du Centre, supplément $\mathrm{n}^{\circ} 51$.

NiERLÉ, M.-C. (1982). Mureybet et Cheik-Hassan (Syrie): outillage de mouture et de broyage (IX-Xème millénaire), Cahiers de l'Euphrate, 3: 177-216.

Pavlu, I. (2000). Double querns. In: Life on neolithic site, Bilany. Situational analysis of artefacts. Académie des sciences tchèques. Prague: 73-98.

Praud, I., Bostyn, F., Cayol, N., Hamon, C., Ladureau, P., LANChon, Y. AND PinARD, E. (2010). Entre Blicquy et Villeneuve-Saint-Germain : présentation de la fouille d'un habitat du Néolithique ancien à Loison-sousLens (Pas-de-Calais). In: C. Marcigny, G. SAN JuAN AND C. Riche (eds). Quoi de neuf à l'ouest: cultures, réseaux et échanges des premières sociétés néolithiques à leur expansion. Actes du 28 e colloque interrégional sur le Néolithique. Presses Universitaires de Rennes.

Procopiou, H., Anderson, P., Formenti, F. and Tresseras, J.J. (2002). Etude des matières transformées sur les outils de mouture: identification des résidus et des traces d'usure par analyse chimique et par observations en microscopie optique et électronique. In: H. Procopiou AND R. Treuil (eds). Moudre et broyer. L'interprétation fonctionnelle de l'outillage de mouture et de broyage dans la Préhistoire et l'Antiquité: actes de la table ronde internationale, Clermont-Ferrand, 30 nov. - 2 déc. 1995. I-Méthodes. CTHS. Paris: 111-27.

Roux, V. (1985). Le matériel de broyage. Etude ethnoarchéologique à Tichitt (R.I) Mauritanie. Edition Recherches sur les civilisations, mémoire $n^{\circ} 58$. Paris.

Schoumacker, A. (1993). Apports de la technologie et de la pétrologie pour la caractérisation des meules. In: P. Anderson, S. Beyries, M. Otte and H. Plisson (eds). Traces et fonction: les gestes retrouvés. Tome I. Colloque international de Liège. Centre de recherche archéologique du CNRS, n50. Éditions ERAUL. Liège: 163-75.

Spatz, H. (1999). Die Mittelneolithische Gäberfeld von Trebur, Kreis Gross-Gerau. Materialen zur voru. frühgeschichte von Hessen, Band 19. Wiesbaden.

Van Gijn, A. and VerbaAs, A. (2009). Reconstructing the life history of querns: the case of the LBK site in Geleen-Janskamperveld (NL). In: M. DE ARAujo IgREJA AND I.C. Conte (eds). Recent Functional Studies on Non-flint Stone Tools: Methodological Improvements and Archaeological Inferences. CDeROM Publication. Lisbon.

Zimmermann, A. (1988). Steine. In: U. Boelicke, D. v. Brandt, J. LÜNIng, P. Stehli and A. Zimmermann (eds). Der bandkeramische Siedlungsplatz Langweiler 8 Gemeinde Aldenhoven. Kr. Düren. Rhein. Ausgr. 28 (Köln/Bonn 1988): 569-787. 
